\title{
THE INFLUENCE OF SPORTS ON HEALTH SCIENCE AND ITS FACTORS
}

\author{
A INFLUÊNCIA DOS ESPORTES NA CIÊNCIA DA SAÚDE E SEUS FACTORES \\ LA INFLUENCIA DEL DEPORTE EN LA CIENCIA DE LA SALUD Y SUS FACTORES
}

Original Article

ARTIGo Original

Artículo Original

Tongyang Chu' 1 D
(Physical Education Professional)

1. Sejong University, 209

Neungdong-ro, Gwangjin-gu,

Seoul, South Korea.

\section{Correspondence:}

Tong yang. Chu.

chutongyang@sina.com

\begin{abstract}
Introduction: Outdoor sports can help people develop good living habits and improve people's physical fitness. For this reason, it is very important to cultivate sports hobbies and analyze the factors of healthy sports. Objective: To understand the factors that affect the healthy sports behavior of college students, we provide a reference for the relevant departments of the school and physical education teachers. Methods: The thesis uses literature data method, questionnaire survey method and mathematical statistics method to analyze sports influencing factors with college students as the research object. Results: The physical education method and the completeness of the facilities will affect the students' interest in sports. Students from different family backgrounds have very different preferences for healthy sports. Conclusions: The school environment and sports atmosphere are the main factors that constitute the school sports environment. College students' cognition and understanding of healthy sports will affect their own sports situation. Level of evidence Il; Therapeutic studies - investigation of treatment results.
\end{abstract}

Keywords: Student Health; Exercise; Healthy Lifestyle; Physical Fitness.

\section{RESUMO}

Introdução: O nivel de aptidão física dos estudantes universitários não só é afetado por fatores subjetivos. Também está intimamente relacionado com a forma como a escola encoraja os alunos a se engajar ativamente en exercícios físicos. Para isso deve criar um excelente ambiente de exercício físico, e estimular o comportamento físico dos estudantes universitários. Somente cultivando bons e saudáveis comportamentos pode ajudar os estudantes universitários a desenvolver o hábito do exercício físico. Objetivo: Compreender os fatores que afetam o comportamento esportivo saudável dos estudantes universitários, fornecer uma base teórica para a formação desses comportamentos, e uma referência para os correspondentes departamentos da escola e os professores de educação física. Métodos: A tese usa o método de dados da literatura, método de levantamento do questionário e método de estatística matemática para conduzir a investigação e análise com estudantes de três faculdades e universidades como objetos de pesquisa. Resultados: As diferenças nos efeitos da educação física, equipamentos, instalações, e sistemas esportivos sobre os comportamentos esportivos saudáveis dos estudantes de diferentes gêneros são muito significativas. Os locais esportivos também têm efeitos diferentes sobre o comportamento dos estudantes. As informações sobre esporte e esporte extracurriculares têm efeitos diferentes. A educação física, os locais de esportes, os sistemas de educação física e os fatores de informação física não têm diferenças significativas nos comportamentos esportivos dos alunos. As diferenças no grau de compreensão e conhecimento do físico e da saúde entre os estudantes influenciam significativamente seus comportamentos esportivos saudáveis. O género não afeta o seu conhecimento da aptidão física e de saúde e os seus comportamentos desportivos. Conclusões: O ambiente esportivo escolar tem efeitos diferentes sobre o comportamento dos estudantes de diferentes graus e gêneros. Os equipamentos e as instalações são os principais fatores que constituem o ambiente esportivo escolar. O grau de compreensão e conhecimento dos conceitos de aptidão física e de saúde dos estudantes afeta a prática do esporte. Nível de evidência ll; Estudos terapêuticos - investigação dos resultados do tratamento.

Descritores: Saúde do estudante; Exercício; Físico Estilo de Vida Saudável; Aptidão Física.

\section{RESUMEN}

Introducción: el nivel físico de los estudiantes universitarios no sólo se ve afectado por factores subjetivos, sino que también está estrechamente relacionado con la forma en que las escuelas alientan a los estudiantes a hacer ejercicio físico activamente, creando un buen entorno de ejercicio físico y cultivando el comportamiento físico de los estudiantes universitarios. Estimular un buen comportamiento saludable de los estudiantes universitarios, puede ayudar a los estudiantes universitarios a desarrollar el hábito del ejercicio físico. Objetivo: comprender los factores que influyen en el comportamiento físico saludable de los estudiantes universitarios, proporcionar una base teórica para la formación de ese comportamiento y crear una referencia para los correspondientes departamentos de la escuela y los profesores de educación física. Métodos: se utilizaron los métodos de documentación, cuestionario y estadísticas matemáticas para investigar los estudiantes de tres universidades. Resultados: la influencia de la educación física, el equipo y el sistema de educación física en el comportamiento físico saludable 
de los estudiantes de diferentes géneros fue significativa. Los estadios y gimnasios también tienen diferentes efectos en el comportamiento deportivo de los estudiantes de diferentes géneros. Los deportes extracurriculares y la información deportiva tienen diversos efectos. No hubo diferencia significativa en el comportamiento físico de los estudiantes en razón del género. La diferencia entre el equipo y los deportes extracurriculares es muy significativa. No hay diferencia significativa entre los diferentes grados de educación física, estadio, sistema de educación física y factores de información deportiva en el comportamiento deportivo de los estudiantes. La diferencia en la comprensión y conocimiento de la salud física entre los estudiantes de diferentes grados tiene un efecto significativo en su comportamiento. El género no tuvo ningún efecto sobre la salud física y el ejercicio. Conclusión: el entorno físico escolar tiene diferentes efectos en el comportamiento físico de los estudiantes de diferentes grados y sexo. El equipo y las instalaciones son los principales factores que componen el entorno deportivo escolar. La comprensión y el conocimiento de los estudiantes universitarios sobre el concepto de salud fisica influyen en la educación física saludable de los estudiantes universitarios. Nivel de evidencia ll; Estudios terapéuticos: investigación de los resultados del tratamiento.

Descriptores: Salud del Estudiante; Ejercicio Físico; Estilo de Vida Saludable; Aptitud Física.

\section{INTRODUCTION}

Healthy sports behavior is the behavior that the subject conducts sports activities in a sports environment to promote physical and mental health, and it is relatively persistent. Therefore, only by cultivating good healthy sports behaviors of college students can they help college students develop the habit of physical exercise. ${ }^{1}$ This is not only conducive to promoting the development of school physical education, but also has important significance in cultivating college students' awareness of lifelong physical exercises. Healthy sports have an important impact on promoting the healthy development of national fitness sports. ${ }^{2}$

\section{METHOD}

\section{General information}

This article selected 781 first-year (from now on referred to as freshman) and second-year (starting now referred to as sophomore) students from three schools as the survey subjects The research objects were factors affecting the healthy sports behaviors of 781 people.

\section{Questionnaire survey method}

According to the research's needs, the researchers issued a total of 800 questionnaires and recovered 790 of them. Nine invalid questionnaires were excluded. Seven hundred eighty-one were valid questionnaires. The effective response rate reached $97.6 \%$.

\section{The validity of the questionnaire}

The initial radius $C$ of Bartlett's sphericity inspection algorithm is usually set to. The initial search stage has a large radius, many detection nodes, and relatively low efficiency. The initial radius formula obtained through engineering experience is

$$
C^{2}=a n \delta^{2}
$$

Where $a$ is the initial radius coefficient, $n$ is twice the number of transmitting antennas and $\delta^{2}$ is the noise variance. In the low signal-to-noise ratio, the search radius will increase with the increase of noise power, which increases the computational complexity. ${ }^{3}$

$$
x_{l}^{m}=\left[x_{l}, x_{l+1}, \cdots, x_{m}\right]^{T}
$$

It is the target vector of the initial radius. The paper set metrics:

$$
\begin{aligned}
& \Delta y_{n, k}=\left\|y_{n, k}-r_{n, n} x_{n, k}\right\|^{2} \\
& \Delta y_{n-1, k}=\left\|y_{n, k}-r_{n-1} x_{n, k}-r_{n-1, n-1} x_{n-1, k}\right\|^{2}
\end{aligned}
$$

Where $\Delta y_{j, k}$ represents the metric value of the k node in the $\mathrm{j}$ layer in the search tree. Among them, the value of $\mathrm{j}$ is $n, n-1, \cdots 1$, and the value of $k$ is affected by the codebook update, and each acquisition can be obtained through the $k=$ length () function. ${ }^{4}$ The relationship between the metric value and the radius can be obtained from the formula (3)

$$
\phi\left(\Delta y_{j, k}\right)=\sum_{j=i}^{n} \Delta y_{j, k}<C^{2}
$$

Arrange the metric values of each layer in ascending order and take $\Delta y_{m, 1}$ as the optimal metric value. From equation (4), we can see that the radius of each layer is

$$
C_{m-1}^{2}=C_{m}^{2}-\Delta y_{m, 1}
$$

\section{Reliability of the questionnaire}

Reliability is a necessary condition for any measurement. Measurements without reliability are meaningless to research. Only measurements with high reliability can provide us with effective and reliable data for analysis and research. The higher the reliability coefficient, the more consistent, stable and reliable the test results. ${ }^{5}$

\section{Mathematical Statistics}

Audit the recovered original data, use Excel 2003 to establish the original database, export the data to SPSS 18.0 statistical software, and use the independent sample t-test method for inspection, analysis, and drawing. ${ }^{6}$

\section{RESULTS}

\section{The influence of school physical environment factors on the} healthy physical behavior of college students

Bandura's ternary determinism shows that environmental factors can intensify the consequences of human behavior. The environment, 
people, and behavior are mutually causal, and each has a two-way decision and interaction relationship, thus forming a system.? (Figure 1)

Environmental factors directly impact human behavior factors and can determine and strengthen human behavior factors. Besides, human behavior, cognition and environment constitute a dynamic interactive decision relationship, and there is a two-way interactive relationship between any two factors.

\section{The impact of school physical environment factors on heal- thy physical behaviors of college students in different grades}

In the school sports environment, students' direct experience or experience through their own sports behavior plays an essential role in cultivating students'awareness of lifelong physical exercise. These direct experiences or experiences play an important role in sport's needs, sports attitudes, sports values and direct sports behavior. It has a positive or negative strengthening effect. From the grouping statistics in Table 1 and the t-test in Table 2. It is known that the equipment and facilities have a more significant impact on the healthy sports behaviors of newcomers and second-year students, and the difference is very significant $(P<0.01)$.

The impact of school sports environmental factors on healthy sports behaviors of college students of different genders

College physical education classes are generally taught separately between male and female students. This kind of "teaching based on sex" and the differences in physical fitness between male and female

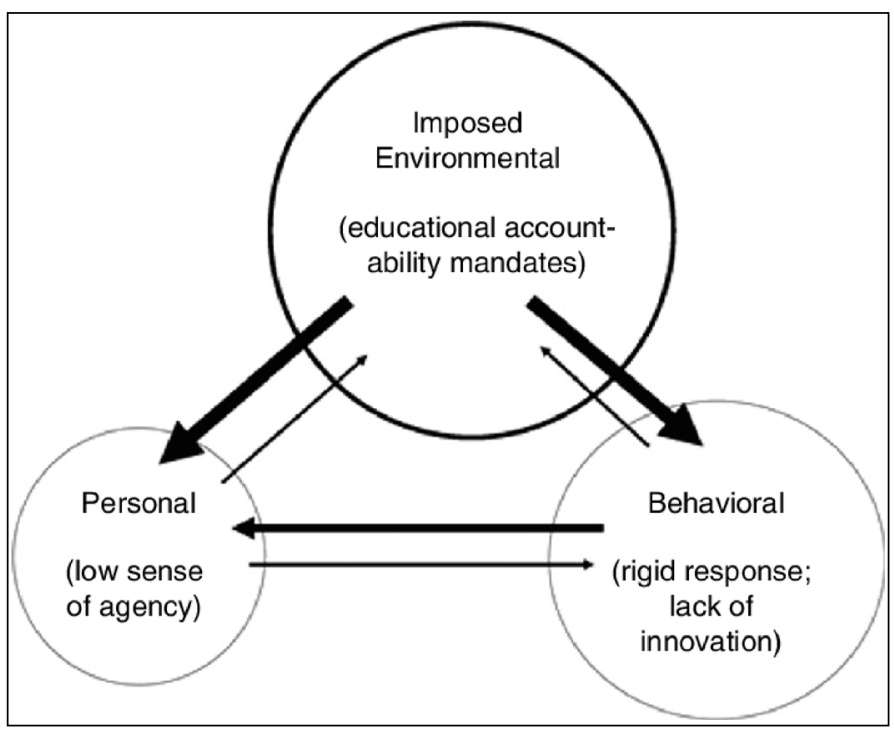

Figure 1. Bandura's ternary determinism model.

Table 1. Group statistics of school sports environment factors on healthy sports behaviors of college students in different grades.

\begin{tabular}{|c|c|c|c|c|c|}
\hline & Grade & $\mathbf{N}$ & Mean & $\begin{array}{l}\text { Standard } \\
\text { deviation }\end{array}$ & $\begin{array}{c}\text { The standard } \\
\text { error of the mean }\end{array}$ \\
\hline \multirow{2}{*}{ Sports venue } & Freshman & 403 & 4.1305 & 0.4631 & 0.02307 \\
\hline & Sophomore & 378 & 4.1265 & 0.55162 & 0.02837 \\
\hline \multirow{2}{*}{$\begin{array}{l}\text { Equipment } \\
\text { and facilities }\end{array}$} & Freshman & 403 & 4.0793 & 0.54614 & 0.0272 \\
\hline & Sophomore & 378 & 3.9263 & 0.58488 & 0.03008 \\
\hline \multirow{2}{*}{$\begin{array}{l}\text { Physical } \\
\text { education }\end{array}$} & Freshman & 403 & 4.2897 & 0.44855 & 0.02234 \\
\hline & Sophomore & 378 & 4.2467 & 0.48054 & 0.02472 \\
\hline \multirow{2}{*}{$\begin{array}{c}\text { Extracurricular } \\
\text { sports }\end{array}$} & Freshman & 403 & 3.8193 & 0.63771 & 0.03177 \\
\hline & Sophomore & 378 & 3.9365 & 0.6197 & 0.03187 \\
\hline \multirow{2}{*}{ Sports system } & Freshman & 403 & 3.7674 & 0.66473 & 0.03311 \\
\hline & Sophomore & 378 & 3.8142 & 0.64534 & 0.03319 \\
\hline \multirow{2}{*}{$\begin{array}{c}\text { Sports } \\
\text { information }\end{array}$} & Freshman & 403 & 3.5327 & 0.75215 & 0.03747 \\
\hline & Sophomore & 378 & 3.6048 & 0.73596 & 0.03785 \\
\hline
\end{tabular}

students have a subtle impact on male and female college students. ${ }^{8}$ Table 3 and Table 4 reflect the impact of school sports environment factors on boy's and girls' healthy sports behaviors.

Table 3 and Table 4 show that among the sports environment factors, the factors that affect the healthy sports behaviors of students of different genders are: sports teaching, equipment and facilities, and sports systems.

Table 2. Independent sample t-tests of school physical education's environmental factors on healthy physical behaviors of college students in different grades.

\begin{tabular}{|c|c|c|c|c|c|}
\hline & & \multicolumn{4}{|c|}{ T-test of the mean equation } \\
\hline & & $\mathrm{t}$ & df & $\begin{array}{l}\text { Sig. } \\
\text { (both sides) }\end{array}$ & $\begin{array}{l}95 \% \text { confidence } \\
\text { in difference }\end{array}$ \\
\hline \multirow{2}{*}{ Sports venue } & A & 0.112 & 779 & 0.911 & -0.0673 \\
\hline & B & 0.111 & 737.822 & 0.911 & -0.06772 \\
\hline \multirow{2}{*}{$\begin{array}{l}\text { Equipment } \\
\text { and facilities }\end{array}$} & A & 3.78 & 779 & 0 & 0.07354 \\
\hline & B & 3.772 & 765.581 & 0 & 0.07336 \\
\hline \multirow{2}{*}{$\begin{array}{l}\text { Physical } \\
\text { education }\end{array}$} & A & 1.294 & 779 & 0.196 & -0.02223 \\
\hline & B & 1.292 & 765.513 & 0.197 & -0.02237 \\
\hline \multirow{2}{*}{$\begin{array}{c}\text { Extracurricular } \\
\text { sports }\end{array}$} & A & -2.601 & 779 & 0.009 & -0.20559 \\
\hline & B & -2.604 & 778.02 & 0.009 & -0.20551 \\
\hline \multirow{2}{*}{ Sports system } & A & -0.997 & 779 & 0.319 & -0.13891 \\
\hline & B & -0.998 & 778.072 & 0.319 & -0.13882 \\
\hline \multirow{2}{*}{$\begin{array}{c}\text { Sports } \\
\text { information }\end{array}$} & A & -1.352 & 779 & 0.177 & -0.17671 \\
\hline & B & -1.353 & 777.604 & 0.176 & -0.17664 \\
\hline
\end{tabular}

Among them, $A$ represents equal variances, and $B$ represents unequal variances.

Table 3. Group statistics of school sports environment factors on healthy sports behaviors of college students of different genders.

\begin{tabular}{c|c|c|c|c|c}
\hline \multirow{2}{*}{ Sports venue } & Grade & $\mathbf{N}$ & Mean & $\begin{array}{c}\text { Standard } \\
\text { deviation }\end{array}$ & $\begin{array}{c}\text { The standard } \\
\text { error of the mean }\end{array}$ \\
\cline { 2 - 6 } & Freshman & 395 & 4.0876 & 0.48188 & 0.02425 \\
\hline \multirow{2}{*}{$\begin{array}{c}\text { Equipment } \\
\text { and facilities }\end{array}$} & Sophomore & 386 & 4.1705 & 0.52989 & 0.02697 \\
\cline { 2 - 6 } & Sophomore & 386 & 3.9216 & 0.58861 & 0.02996 \\
\hline \multirow{2}{*}{$\begin{array}{c}\text { Physical } \\
\text { education }\end{array}$} & Freshman & 395 & 4.2191 & 0.49163 & 0.02474 \\
\cline { 2 - 6 } & Sophomore & 386 & 4.3198 & 0.42971 & 0.02187 \\
\hline \multirow{2}{*}{$\begin{array}{c}\text { Extracurricular } \\
\text { sports }\end{array}$} & Freshman & 395 & 3.8881 & 0.65933 & 0.03317 \\
\cline { 2 - 6 } & Sophomore & 386 & 3.8636 & 0.60204 & 0.03064 \\
\hline \multirow{2}{*}{\begin{tabular}{c} 
Sports system \\
\cline { 2 - 6 }
\end{tabular}} & Freshman & 395 & 3.8759 & 0.68021 & 0.03422 \\
\cline { 2 - 6 } $\begin{array}{c}\text { Sports } \\
\text { information }\end{array}$ & Sophomore & 386 & 3.7021 & 0.61763 & 0.03144 \\
\cline { 2 - 6 } & Sreshman & 395 & 3.5756 & 0.74558 & 0.03751 \\
\hline
\end{tabular}

Table 4. Independent sample t-test of school sports'environmental factors on healthy sports behaviors of college students of different genders.

\begin{tabular}{|c|c|c|c|c|c|}
\hline & & \multicolumn{4}{|c|}{ T-test of the mean equation } \\
\hline & & $\mathbf{t}$ & df & $\begin{array}{c}\text { Sig. } \\
\text { (both sides) }\end{array}$ & $\begin{array}{l}95 \% \text { confidence } \\
\text { in difference }\end{array}$ \\
\hline \multirow[t]{2}{*}{ Sports venue } & A & -2.288 & 779 & 0.022 & -0.01176 \\
\hline & $B$ & -2.285 & 768.361 & 0.023 & -0.01168 \\
\hline \multirow{2}{*}{$\begin{array}{l}\text { Equipment } \\
\text { and facilities }\end{array}$} & A & 4.095 & 779 & 0 & 0.24469 \\
\hline & $B$ & 4.091 & 769.723 & 0 & 0.24477 \\
\hline \multirow{2}{*}{$\begin{array}{l}\text { Physical } \\
\text { education }\end{array}$} & $A$ & -3.044 & 779 & 0.002 & -0.03576 \\
\hline & $B$ & -3.049 & 769.53 & 0.002 & -0.03586 \\
\hline \multirow{2}{*}{$\begin{array}{c}\text { Extracurricular } \\
\text { sports }\end{array}$} & A & 0.543 & 779 & 0.587 & 0.1133 \\
\hline & $B$ & 0.544 & 775.45 & 0.587 & 0.1132 \\
\hline \multirow[t]{2}{*}{ Sports system } & A & 3.737 & 779 & 0 & 0.2652 \\
\hline & B & 3.742 & 774.844 & 0 & 0.2651 \\
\hline \multirow{2}{*}{$\begin{array}{c}\text { Sports } \\
\text { information }\end{array}$} & A & 0.305 & 779 & 0.761 & 0.12094 \\
\hline & B & 0.305 & 778.622 & 0.761 & 0.12094 \\
\hline
\end{tabular}




\section{The influence of the degree factors of college students' cog- nitive physique concept on their healthy sports behaviors}

The subjective evaluation of physical self-cognition and the objective evaluation of college students' physical fitness levels of different grades are relatively different. This difference is closely related to college students' awareness of the importance of sports and their awareness of participating in sports, which leads to cognition. Deviations in the concept of the physique (Table 5).

From the grouping statistics in Table 5, we know that the average values of the degree of cognition of the physical fitness concept of the freshman and sophomore students are 3.50 and $3.68 .{ }^{9}$

Table 5. Group statistics of different grades of college students' cognition of physical fitness and health concepts and their healthy sports behaviors.

\begin{tabular}{c|c|c|c|c|c}
\hline & grade & $\mathbf{N}$ & Mean & $\begin{array}{c}\text { Standard } \\
\text { deviation }\end{array}$ & $\begin{array}{c}\text { The standard } \\
\text { error of the mean }\end{array}$ \\
\hline \multirow{2}{*}{\begin{tabular}{c} 
Sports venue \\
\cline { 2 - 6 }
\end{tabular}} & Freshman & 403 & 4.1305 & 0.4631 & 0.02307 \\
\hline $\begin{array}{c}\text { Cognition of } \\
\text { the concept of } \\
\text { physical fitness }\end{array}$ & Freshman & 403 & 3.5 & 0.805 & 0.04 \\
\cline { 2 - 6 } & Sophomore & 378 & 3.68 & 0.695 & 0.036 \\
\hline $\begin{array}{c}\text { Awareness of } \\
\text { health concepts }\end{array}$ & Freshman & 403 & 3.23 & 0.677 & 0.034 \\
\cline { 2 - 6 } & Sophomore & 378 & 3.56 & 0.629 & 0.032 \\
\hline
\end{tabular}

\section{DISCUSSION}

The influence of the degree factors of college students' cognitive health concept on their healthy sports behaviors

Health is physical freedom from disease and mental health, with good social adaptability and sound moral and health qualities. ${ }^{10}$ Health is a sufficient and necessary condition for an individual to obtain minimum happiness in the long term.

Different age groups have different perceptions of health, which are closely related to living habits, knowledge level, own health status, social, environmental factors, etc. The existence of these factors more or less affects their healthy sports behaviors. ${ }^{11}$ Most students have a superficial knowledge of health concepts and do not have enough awareness to improve their health. It reflects that the more sports and health knowledge that sophomore students come into contact with or master, the more they have a deeper understanding of the concept of health.

\section{Related suggestions}

Physical education should focus on the "three basics"teaching, help college students establish the "health first" idea, enhance their awareness of sports and health knowledge, promote their healthy behavior motivation, and form good healthy sports behaviors. ${ }^{12}$ Schools should create conditions to meet the hardware environment of students' physical exercise needs. The development of extracurricular sports should focus on physical exercise and fun, pay attention to students' participation and participation so that students can fully enjoy the fun of sports activities, strengthen their physique, and promote physical and mental health.

\section{CONCLUSION}

The quality of the physical education environment affects the healthy physical behavior of college students. Equipment and physical education are the main factors that constitute the school sports environment, and they are a double-edged sword that affects college students'healthy sports behavior. The sports system plays an essential role in guiding and regulating healthy sports behaviors and guarantees promoting healthy sports behaviors of college students. Extracurricular sports can help students form good sports and healthy behaviors and gradually cultivate their interest in sports. The school sports environment has different effects on students' healthy sports behaviors of different grades and genders. The sports behaviors of college students of different grades are closely related to equipment and extracurricular sports. The degree of understanding and cognition of physical fitness and health of college students affects their health.

The author declare no potential conflict of interest related to this article

AUTHORS' CONTRIBUTIONS: The author made significant contributions to this manuscript. TC: writing and performing surgeries; data analysis and performing surgeries; article review and intellectual concept of the article.

\section{REFERENCES}

1. Al Bimani $S A$, Gates $L S$, Warner $M$, Bowen C. Factors influencing return to play following conservatively treated ankle sprain: a systematic review. Phys Sportsmed. 2019;47(1):31-46.

2. O'Leary $N$, Longmore C, Medcalf R. Factors influencing a physical education teacher's pedagogical games practices with pupils experiencing social, emotional and mental health issues. Eur Phys Educ Rev. 2020;26(2):305-21.

3. Kaplan $Y$, Witvrouw E. When is it safe to return to sport after $A C L$ reconstruction? Reviewing the criteria. Sports Health. 2019;11(4):301-305.

4. Patatas JM, De Bosscher V, Derom I, De Rycke J. Managing parasport: An investigation of sport policy factors and stakeholders influencing para-athletes' career pathways. Sport Management Review. 2020 [cited 202111 Jun];23(5): 937-51. Available from: https://ideas.repec.org/a/eee/ spomar/v23y2020i5p937-951.html

5. Moore E, Chalmers S, Milanese S, Fuller JT. Factors influencing the relationship between the functional movement screen and injury risk in sporting populations: a systematic review and meta-analysis. Sports Med. 2019;49(9):1449-63.

6. Lininger MR, Wayment HA, Craig DI, Huffman AH, Lane TS. Improving Concussion-Reporting behavior in national collegiate athletic association division I football players: evidence for the applicability of the Socioecological model for athletic trainers. J Athl Train. 2019;54(1): 21-9.
7. M'mbaha JM, Chepyator-Thomson JR. Factors influencing career paths and progress of Kenyan women in sport leadership. Qual Res Sport Exerc Health. 2019 [cited 202111 Jun];11(3):316-33. Available from: https://www.tandfonline.com/doi/abs/10.1080/2159676X.2018.1446042

8. Long, M. Key Factors of students' participating in ecology sports motivation. Ekoloji. 2019 [cited 202111 Jun];28(107):1599-603. Available from: http://www.ekolojidergisi.com/download/key-factors-of-students-participating-in-ecology-sports-motivation-5785.pdf

9. Andersen MH, Ottesen L, Thing LF. The social and psychological health outcomes of team sport participation in adults: An integrative review of research. Scand J Public Health. 2019;47(8):832-50.

10. Truong LK, Mosewich AD, Holt CJ, Le CY, Miciak M, Whittaker JL. Psychological, social and contextual factors across recovery stages following a sport-related knee injury: a scoping review. Br J Sports Med. 2020;54(19):1149-56.

11. Tun M, Ratanawijitrasin S, Phukao D, Peak SC. Quantitative cross sectional survey of women's beliefs as influencing factors in the utilization of antenatal services in three townships of Chin state, Myanmar. Journal of Health, Medicine and Nursing. 2021 [cited 202111 Jun];6(1): 40-52. Available from: https://www.iprjb.org/journals/index.php/JHMN/article/view/1216/1334

12. Cross R, Siegler J, Marshall $P$, Lovell R. Scheduling of training and recovery during the in-season weekly micro-cycle: Insights from team sport practitioners. Eur J Sport Sci. 2019;19(10):1287-96. 